\title{
PRAGMATICS OF COMMUNICATIVE TONALITY IN THE STYLISTICS OF ENGLISH EDUCATIVE CONVERSE
}

\author{
Elena Yu. Ilyinova \\ Volgograd State University, Volgograd, Russia \\ Tamara N. Tsinkerman \\ Volgograd State University, Volgograd, Russia
}

\begin{abstract}
The article is devoted to the study of communicative tonality that is considered a dynamic linguisticand-pragmatic characteristic of the communication style, which is actualized by the choice of language means and speech techniques, correlated with the strata-tactical and genre-stylistic features of a particular kind of discourse. The corpus of educative parent-child dialogue examples allowed to identify the main goal of this discourse type, that is the child's socialization in the course of communication based on adult status dominance, to determine four styles of educative communication that differ in patterns of functional and syntactic speech models and in language means which are a part of the communicative competence of English-speaking culture. The linguistic-and-pragmatic analysis of adults' speech utterances revealed the specificity of stratagem-tactical intentions in choosing each style of educative communication, made it possible to designate the character of illocution, aimed at explicating the intent to socialize a child through explaining, persuading, reasoning, suggesting, compelling and criticizing behavior. The analysis of pragmatic markers of the communication tonality revealed its hybrid and modulated character, that is shown in a meaningful choice of functional-syntactic models of speech, in direct or indirect forms of empathy types - from democratic, consolidating to moralizing and adversarial. According to the study, the tonality of educative communication varies from strong and soft shades of benevolent, trustful, playful, serious, and indulgent to instructive, mentor, contemptuous, ironically mocking tones, which can be expressed in different combinations of lexical, stylistic and functional-pragmatic means of English.

Key words: discourse, educative discourse, linguistic-and-pragmatic analysis, communicative tonality, educative communicative style, intention, converse tactics, converse strategy.

Citation. Ilyinova E.Yu., Tsinkerman T.N. Pragmatics of Communicative Tonality in the Stylistics of English Educative Converse. Vestnik Volgogradskogo gosudarstvennogo universiteta. Seriya 2, Yazykoznanie [Science Journal of Volgograd State University. Linguistics], 2019, vol. 18, no. 1, pp. 146-158. (in Russian). DOI: https:// doi.org/10.15688/jvolsu2.2019.1.12
\end{abstract}

\section{ПРАГМАТИКА КОММУНИКАТИВНОЙ ТОНАЛЬНОСТИ В СТИЛИСТИКЕ АНГЛОЯЗЫЧНОГО ВОСПИТЫВАЮЩЕГО ДИАЛОГА}

\author{
Елена Юрьевна Ильинова \\ Волгоградский государственный университет, г. Волгоград, Россия \\ Тамара Николаевна Цинкерман \\ Волгоградский государственный университет, г. Волгоград, Россия
}

Аннотация. Статья посвящена изучению категории коммуникативной тональности, которая рассматривается как динамичная лингвопрагматическая характеристика стиля общения, реализуемая выбором языковых средств, речевых приемов, соотносящихся со стратагемно-тактическими и жанрово-стилистическими особен- 
ностями отдельной разновидности дискурса. На корпусе англоязычных примеров воспитывающего диалога родителя с ребенком выделена основная задача и охарактеризована прагматика данной разновидности дискурса - социализация ребенка в ходе общения, основанного на статусном доминировании взрослого; установлены четыре стиля воспитывающего общения, различающиеся набором функционально-синтаксических моделей речи и языковых средств, входящих в общий фонд коммуникативной компетенции носителей англоязычной культуры. Лингвопрагматический анализ речевых высказываний взрослых позволил уточнить специфику реализации стратагемно-тактических интенций при выборе каждого стиля и тональности воспитывающего общения, отметить особенности иллокуции, нацеленной на социализацию ребенка с помощью объяснения, убеждения, уговора, внушения, принуждения, критики поведения ребенка. Выявленные коммуникативно-прагматические маркеры тональности указывают на гибридный характер использования стилей воспитывающего общения, который описан как механизм лингвопрагматической модуляции, отраженный в осмысленном выборе функционально-синтаксических моделей речи, что позволяет в открытой или непрямой форме оказывать разные по степени эмпатии виды воздействия на ребенка - от демократического, консолидирующего до морализаторского и агонального. По данным исследования, тональность воспитывающего общения варьируется от сильных и мягких оттенков доброжелательного, доверительного, шутливого до серьезного, снисходительного, поучающего, менторского, презрительного, иронично-насмешливого тона, что получает выражение в разных сочетаниях лексико-стилистических и функционально-прагматических средств английского языка.

Ключевые слова: дискурс, воспитательный дискурс, лингвопрагматический анализ, коммуникативная тональность, стиль воспитывающего общения, интенция, речевая тактика, речевая стратегия.

Цитирование. Ильинова Е. Ю., Цинкерман Т. Н. Прагматика коммуникативной тональности в стилистике англоязычного воспитывающего диалога // Вестник Волгоградского государственного университета. Серия 2, Языкознание. -2019. - Т. 18, № 1. - C. 146-158. - DOI: https://doi.org/10.15688/jvolsu2.2019.1.12

\section{Введение}

Термин тональность представляется значимым для описания особенностей речевой практики человека, однако его использование в рамках теории дискурса требует научного обоснования.

В работах, посвященных изучению устной речи, тональность считают значимой характеристикой, отражающей такие тональные составляющие, как интонация, паузы, диапазон голоса [Алексеева, 2013, с. 124]. Длительное время феномен тональности ассоциировался в лингвистике в первую очередь с представлением о содержательной организации литературного текста. Так, по мнению Т.В. Матвеевой, тональностью (текстовой экспрессивностью) следует называть текстовую категорию, в которой находит выражение «эмоционально-волевая установка автора текста при достижении конкретной коммуникативной цели» [Матвеева, 2003, с. 549]. Она входит в состав категории субъектности речевого произведения, поскольку отражает личностную (психологическую) позицию автора по отношению к излагаемому [Матвеева, 2003, с. 549].

В связи с активизацией исследований в области теории дискурса проявляется интерес к функциональному аспекту категории то- нальности как субъектно-личностной позиции человека в практике речевого общения. На особую роль экспрессивности в разных формах речевого общения указывал М.М. Бахтин. В работе «Проблема речевых жанров» ученый отмечал, что «в разных сферах речевого общения экспрессивный момент имеет разное значение и разную степень силы, но есть он повсюду: абсолютно нейтральное высказывание невозможно» [Бахтин, 1997, с. 188]. Под экспрессивным моментом известный теоретик литературы, очевидно, понимал «оценивающее отношение говорящего к предмету речи» [Бахтин, 1997, с. 188]; оно возникает лишь тогда, когда происходит «контакт языка с действительностью» [Бахтин, 1997, с. 191]. Представляется, что М.М. Бахтин дал этому явлению логичное объяснение - экспрессия чужда слову, она возникает лишь в процессе живого общения и составляет тот конструктивный элемент, который делает текст индивидуальным, определяет его стиль и композицию. В исследованиях отечественных авторов экспрессивность высказывания мыслится как фактор психологического самораскрытия, обладающего в устной речи эффектом усиления воздействия на адресата [Матвеева, 2003, с. 549], то есть с помощью разных вербальных средств передаются модаль- 
ности волеизъявления, эмоциональной оценки, интенсивности и прочие оттенки прагматики общения. В публикациях зарубежных авторов также подчеркивается коммуникативно-прагматическая функция тональности речи, позволяющая влиять на отношения между коммуникантами: «Tonality is all about how you sound when you speak $<\ldots>$ When you are talking with an audience, you are going to want to use a voice that both commands attention and conveys authority...» [The Accidental Communicator]. В зависимости от типа или формы речевого воздействия отдельные авторы выделяют некоторые разновидности тональности, напр., мажорную, отражающую общий оптимистический настрой, положительные эмоции и оценки; минорную, передающую пессимистический настрой, отрицательные эмоциональные оценки; нейтральную, с эмоциональной оценочностью равной нулю, что приближает общение к объективному, затемняющему личностную позицию говорящего [Матвеева, 2003, с. 549]. Известны и иные критерии типологизации тональности, основанные на оценке эмоционально-стилевого формата общения, в рамках которого проявляются маркеры градуальности субъективности в отдельном типе коммуникации. Так, В.И. Карасик предложил выделять перформативные разновидности серьезного и несерьезного типа общения [Карасик, 2013, c. 149], отражающие статусные и индивидуальные характеристики дискурсивной личности [Карасик, 2013, с. 150].

Приведенные сведения указывают на возможность использования термина тональность для описания коммуникативной компетенции, варьировать приемы выражения смысла и мнения в устном общении с помощью выбора стиля общения как намеренного набора номинативных приемов, синтаксических моделей построения высказывания, указывающих на субъектно доминирующую позицию человека, участвующего в коммуникации. В работах отечественных специалистов по функциональной стилистике неоднократно указывалось на энтропию текста, тональное содержание функционального стиля [Гальперин, 2005], в теории дискурса - на наличие текстовой константы, объединяющей разные эмотивные и волюнтативные характеристики речи, позволяющие определить по тональнос- ти стиль общения или состояние отношений между коммуникантами [Эффективное речевое общение, 2012, с. 719-721]. Как коммуникативная категория тональность соотносится с выражением позиции субъекта в высказывании или целом тексте (напр., «эмоциональная окраска речи» [Грановская, 2007, с. 28], «вид субъективной модальности как средство выражения оценочности» [Тупикова, 2011, с. 68]). Таким образом, представляется значимым уточнение содержания термина тональность по отношению к коммуникативным стратегиям и тактикам дискурса и единицам языка, реализующим функции оформления речи в определенном стилевом регистре.

В данной статье коммуникативную тональность предлагается рассматривать как категорию дискурса, объединяющую фоностилистические и прагмалингвистические характеристики речевой практики, погруженной в те или иные социальные условия общения. Важным для нашего исследования считаем такое определение функции тональности: с помощью намеренного выбора коммуникативных действий регулировать межличностные отношения в ходе общения, оформляя речь в том или ином стилевом регистре, отражая таким образом субъективно-оценочное отношение к ситуации. Предлагаемое понимание категории коммуникативная тональность согласуется с современным представлением о формате общения и приемах его воплощения в речи. В работах В.И. Карасика под коммуникативной тональностью предлагается понимать «эмоционально-стилевой формат общения, возникающий в процессе взаимовлияния коммуникантов и определяющий их меняющиеся установки и выбор всех средств общения» [Карасик, 2007, c. 384]. Развивая идею о прагматической значимости категории коммуникативной тональности, ученый приходит к выводу о ее дискурсивно-вариативной природе. Эмоциональностилевое разнообразие речевого поведения представляется отражением способности дискурсивной личности выбирать личностно маркированные приемы общения, позволяющие указывать на такие признаки общения, как градация дистанцирования и границ приватности человека, настроенность на особые приемы выражения мыслей, обусловленные личностными интенциями [Карасик, 2013, с. 159-160]. 
Принимая приведенные характеристики коммуникативной тональности как специфической категории дискурса, точно указывающей на функцию рассматриваемого дискурсивного феномена - быть средством управления тактическими конвенциями в общении, подчеркнем, что коммуникативная тональность, кроме дискурсивной универсальности, отличается этнокультурной обусловленностью и вариативностью приемов реализации в разных коммуникативных условиях (подробно об этом см.: [Карасик, 2008]). «Конвенция заданности или закодированности информации со стороны отправителя» определяет то, что тональность в зависимости от коммуникативной цели и личностных мотивов говорящего, а также под влиянием изменившихся условий коммуникативной ситуации может преобразовываться и в личностно-ориентированном (бытовом и бытийном), и в статусно-ориентированном дискурсах [Карасик, 2008, с. 20]. Таким образом, категория коммуникативной тональности является важной характеристикой любого стиля общения, поскольку отвечает не только за выражение отношения говорящего к обсуждаемой теме или партнеру по коммуникации, но и за управление ходом общения, поскольку проектирует его эмоционально-оценочный фон. Тональность как модусная категория, сопровождая манеру общения, стиль речи в каждой отдельной ситуации, позволяет адресанту передать свои намерения, а адресату распознать эти намерения и выбрать соответствующий личной субъективной позиции стиль продолжения общения.

Приведенные мнения лингвистов позволяют выдвинуть предположение, что терминологическое сочетание коммуникативная тональность точно указывает на важную коммуникативную функцию языка - при реализации в тексте / дискурсе быть средством воплощения тактических конвенций общения, допускающих дискурсивную вариативность, зависящую от социальных и этнокультурных условий и личностных целей общения. Для раскрытия содержания данной категории дискурса и уточнения приемов ее реализации в речевой практике в статье обосновывается концепция модуляционного характера коммуникативной тональности, отражае- мого в вариативности коммуникативных тактик и лингвистических приемов реализации личностных интенций на основе лингвопрагматической интерпретации англоязычных высказываний в типовых ситуациях воспитывающего дискурса.

\section{Принципы и методика изучения коммуникативной тональности в стилистике воспитывающего общения}

Изучение языковых и текстовых проявлений коммуникативной тональности следует начать с уточнения представлений о коммуникативном стиле в теории дискурса и методиках извлечения прагматических интенций говорящего с помощью анализа языковых средств.

Коммуникативный стиль рассматривают в теории дискурса как многоплановый конструкт, отражающий своим составом сложность и неоднозначность условий реального общения [Карасик, 2008; 2013; Куликова, 2011; Тупикова, 2011; Hunter, 1994 и др.]. Отдельные исследователи предлагают при изучении коммуникативного стиля учитывать тип культуры и индивидуальную привлекательность коммуниканта с позиций его поведения по отношению к партнеру по коммуникации. Р. Нортон и Л. Петегрю определяют коммуникативный стиль как способ или манеру вербального, невербального и паравербального поведения человека, требующего интерпретации («the way one verbally, nonverbally, and paraverbally interacts to signal how literal meaning should be taken, interpreted, filtered, or understood» [Norton, Pettegrew, 1977, p. 260]). На основании возможных форм коммуникативного поведения человека и имеющихся данных о постоянных и переменных характеристиках речи указанные авторы выделили систему из десяти стилей коммуникации: dominant (доминирующий), friendly (дружелюбный), attentive (внимательный), relaxed (мягкий), contentious (агрессивный), dramatic (драматичный), animated (динамичный), open (открытый), impression-leaving (не/оставляющий впечатление), communicator image (положительный / отрицательный коммуникатор) [Norton, Pettegrew, 1977, с. 260-261]. В зависимости от психотипа личности и интенций рассматриваются 
группы активного и пассивного стилей общения, в частности, assertive (настойчивый убеждающий), aggressive (настойчивый инициативный), manipulative (манипулятивный), а также passive-submissive (уступчивый), passive-aggressive (настроенный на защиту). В этих системах коммуникативная тональность рассматривается как вариативность речевого поведения, призванная выразить с помощью выбора коммуникативных действий личные мотивы коммуникантов.

В проводимом нами исследовании система коммуникативных действий, характерная для отдельного типа дискурса и транслирующая информацию об эмоционально-оценочных признаках коммуникации, рассматривается как «стиль общения»модусная категория, представляющая один из возможных типов общения, который отличается специфической манерой речевого поведения, намеренно избираемой говорящим для реализации стратегической задачи, основной и дополнительных интенций, соотносимых с избранными тактиками и способами их речевого воплощения. Посредством речевых действий, построенных по типовым синтаксическим моделям национального языка в сопровождении определенной коммуникативной тональности, говорящие пытаются управлять коммуникативным поведением, воплощать личные интенции. В ходе динамичной и ситуативно изменчивой коммуникации они вынуждены постоянно корректировать ход и стиль общения. При этом возможности выбора языковых средств из устойчивых систем коммуникативных действий, реализуемых в типовых условиях взаимодействия, несколько ограничены сценарными нормами поведения на отдельном национальном языке.

Именно это наблюдение позволило нам сформулировать гипотезу о прагматическом характере коммуникативной тональности, обусловленном механизмом модуляции манеры общения. Для обоснования научной значимости данной категории и выявления приемов ее реализации в границах отдельной разновидности дискурса - англоязычного воспитывающего диалога родителя с ребенком - были проанализированы скрипты 29 эпизодов образовательной программы для обучения родителей адекватным формам общения с детьми (общей продолжительностью 230 мин.) и скрипты 2 художественных фильмов (общей продолжительностью 220 мин.) (см. Источники).

Воспитательный дискурс представляет собой особую форму педагогического воздействия, нацеленного на социализацию ребенка, его характеризует статусная асимметрия участников (взрослый - ребенок), жанровое и стилевое своеобразие общения, которое инициируется и направляется воспитателем. Для уточнения специфики лингвистической прагматики в речи взрослого было проведено параметрическое моделирование англоязычного воспитательного дискурса с учетом общих норм индивидуалистической культуры: privacy, individualism, autonomy, freedom from imposition, а также объектных (compliance, awareness, responsibility) и субъектных (selfawareness, self-esteem, self-responsibility) мотивов воздействий взрослого на ребенка [Ларина, 2013; Леонтович, 2002; Hunter, 1994; Pearson et al., 2012 и др.]. Речевое поведение взрослого отличается этнокультурно маркированной совокупностью коммуникативных действий, с помощью которых реализуются макро- и микроинтенции воспитывающего воздействия при соблюдении принципов коммуникативной неимпозитивности и неприкосновенности личности, доминирующих в англосаксонской культуре межличностного общения [Цинкерман, 2015].

Стиль общения в своем исследовании мы соотносим с представлением о типичной манере коммуникативной деятельности, маркированной системой коммуникативных единиц, реализующих интенции, стратегии, тактики общающихся, субъективность их межличностных отношений и эмоций с поправкой на меняющиеся условия коммуникации. В реальном общении коммуникативные стили не носят строго ограничивающий поведение коммуниканта характер. Из потенциально возможных стилей общения, составляющих основу дискурсивной компетенции личности, представляется возможным избирать разные варианты коммуникативных действий и воплощать с их помощью индивидуально-личностные интенции, в том числе в ситуациях воспитывающего воздействия. 
Для проведения лингвопрагматического анализа тональности общения в качестве основной единицы наблюдения было избрано высказывание, реализующее вариативность коммуникативного поведения в границах избранной формы дискурса - воспитывающего диалога, предполагающего владение взрослыми некоторым набором коммуникативных действий, объединенных общей стратегической задачей воспитывающего общения - социализацией ребенка (формированием нормативных моделей поведения и развитием личности), но обладающих потенциалом лингвопрагматической модуляции приемов речевого воздействия, связанным с динамикой ситуации и психологическими особенностями личности взрослого, вступающей в общение с ребенком.

В основу лингвопрагматического анализа была положена процедура интерпретации иллокутивной силы высказываний, представленных в типовых синтаксических моделях английского предложения (утверждение, вопрос, императив, экскламатив), с последующей систематизацией коммуникативных действий, позволяющих реализовать основную цель воспитательного дискурса посредством четырех стратегий: кооперативной, покровительственной, директивной, разъяснительной, которые определяют наличие демократического, патерналистского, авторитарного, интерпретативного стилей воспитывающего дискурса [Ильинова, Цинкерман, 2015]. В дальнейшем проводился поиск лексико-стилистических знаков, указывавших на тональности общения в воспитывающих диалогах (напр., присутствие хвалебной, критичной, сниженной, инвективной лексики), устанавливались прагмасинтаксические признаки коммуникативной тональности высказывания как специфические проявления стилистики англоязычного воспитывающего общения. В следующем разделе статьи обосновывается положение о том, что в сознании взрослого человека складывается особая когнитивно-дискурсивная модель речевого поведения, с помощью которой представляется возможным не только передавать основную информацию, но и выражать отношение к содержанию речи, а также воздействовать на личность ребенка.

\section{Результаты и обсуждение}

Коммуникативная тональность представляется значимой характеристикой каждого из выделенных нами стилей воспитывающего общения. В процессе воспитательного взаимодействия взрослый решает разные задачи социализации и, меняя типы коммуникативных действий в сопровождении модуляции коммуникативных тональностей, склоняет ребенка к согласию, послушанию, логичным действиям, эмпатии.

Лингвопрагматическая интерпретация иллокутивной силы речевых актов с интенцией воспитывающего воздействия на ребенка позволила выявить набор повторяющихся приемов передачи коммуникативной тональности, характерный для каждого стиля воспитывающего общения, при этом был отмечен гибридный характер их использования в реальном общении. Гибридность предполагает чередование и сочетание признаков разных стилей и коммуникативных тональностей в границах речевых партий взрослых. В таблице представлены закономерные соответствия между разновидностями коммуникативной тональности, иллокутивной силой высказываний, синтаксическими и лексическими предпочтениями при их реализации.

Выявленные дискурсивные и языковые признаки свидетельствуют о совмещении в трех англоязычных стилях воспитывающего воздействия таких тональностей, как дружелюбная, доброжелательная, доверительная, морализаторская, однако при совпадении иллокутивных целей высказываний было отмечено своеобразие их прагматики и реализаций в языковых знаках. В частности, модуляции проявляются при смене коммуникативной тональности в рамках одного стиля общения, гибридность наблюдается в модуляциях между демократическим, интепретативным и патерналистским стилями, нацеленными на усиление эффекта воспитывающего воздействия, авторитарный стиль характеризуется доминированием языковых средств давления и унижения ребенка. Для подтверждения приведем примеры, демонстрирующие чередование тактик и стилей в речи взрослого, когда он пытается с помощью тонально-стилевой модуляции своих высказываний регулировать поведение ребенка в пространстве англоязычного воспитательного дискурса. 


\section{Сопоставление признаков коммуникативной тональности}

\section{для стилей воспитывающего диалога}

\begin{tabular}{|c|c|c|c|c|c|}
\hline $\begin{array}{c}\text { Коммуника- } \\
\text { тивный } \\
\text { стиль } \\
\text { обшцения }\end{array}$ & $\begin{array}{c}\text { Разновидность } \\
\text { коммуникатив- } \\
\text { ной тональности }\end{array}$ & $\begin{array}{c}\text { Иллокутивная } \\
\text { цель }\end{array}$ & $\begin{array}{c}\text { Дискурсивнье } \\
\text { признаки } \\
\text { тональности }\end{array}$ & $\begin{array}{c}\text { Синтаксические } \\
\text { средства передачи } \\
\text { тональности }\end{array}$ & $\begin{array}{c}\text { Лексические } \\
\text { средства передачи } \\
\text { тональности }\end{array}$ \\
\hline $\begin{array}{l}\text { Демократи- } \\
\text { ческий / ин- } \\
\text { терпрета- } \\
\text { тивный }\end{array}$ & $\begin{array}{l}\text { доброжелатель- } \\
\text { ная, } \\
\text { дружелюбная, } \\
\text { доверительная, } \\
\text { серьезная }\end{array}$ & $\begin{array}{l}\text { демонстрация } \\
\text { уважения, го- } \\
\text { товности к со- } \\
\text { трудничеству; } \\
\text { разделение от- } \\
\text { ветственности; } \\
\text { предоставле- } \\
\text { ние права вы- } \\
\text { бора }\end{array}$ & $\begin{array}{l}\text { вежливость, } \\
\text { неимпозитивность, } \\
\text { сдержанная эмо- } \\
\text { циональность, } \\
\text { четкая мена ролей, } \\
\text { условная симмет- } \\
\text { ричность речевых } \\
\text { ролей, } \\
\text { коммуникативная } \\
\text { толерантность, } \\
\text { тематические по- } \\
\text { вторы } \\
\end{array}$ & $\begin{array}{l}\text { неимперативные } \\
\text { формы утверждений } \\
\text { и обращений; } \\
\text { условные и гипоте- } \\
\text { тические модальные } \\
\text { предикаты; } \\
\text { условные предло- } \\
\text { жения; } \\
\text { вежливые побуди- } \\
\text { тельные предложе- } \\
\text { ния переспросы- } \\
\text { уточнения }\end{array}$ & $\begin{array}{l}\text { стилистически ней- } \\
\text { тральная лексика, } \\
\text { перфомативные гла- } \\
\text { голы речемыслитель- } \\
\text { ной деятельности в } \\
\text { сочетании с mbl- } \\
\text { обращением к ребен- } \\
\text { ку; модальные глаго- } \\
\text { лы can / could / would }\end{array}$ \\
\hline $\begin{array}{l}\text { Патернали- } \\
\text { стский / ин- } \\
\text { терпрета- } \\
\text { тивный }\end{array}$ & $\begin{array}{l}\text { снисходительное } \\
\text { дружелюбие; } \\
\text { покровительст- } \\
\text { венная, } \\
\text { снисходительная, } \\
\text { морализатор- } \\
\text { ская }\end{array}$ & $\begin{array}{l}\text { демонстрация } \\
\text { волитивности } \\
\text { и доминирова- } \\
\text { ния взрослого }\end{array}$ & $\begin{array}{l}\text { импозитивность / } \\
\text { неимпозитивность; } \\
\text { асимметрия объе- } \\
\text { ма высказываний } \\
\text { взрослого; } \\
\text { мотивированные } \\
\text { запреты }\end{array}$ & $\begin{array}{l}\text { сослагательное на- } \\
\text { клонение, } \\
\text { директивы, модаль- } \\
\text { ные фразы предска- } \\
\text { зания в сочетании с } \\
\text { местоимением уои, } \\
\text { советы }\end{array}$ & $\begin{array}{l}\text { стилистически ней- } \\
\text { тральная лексика, } \\
\text { оценочные наречия } \\
\text { too / enough в сочета- } \\
\text { нии с прилагательны- } \\
\text { ми young / old; } \\
\text { доминирование лич- } \\
\text { ного местоимения I } \\
\text { или притяжательного } \\
\text { местоимения my в ре- } \\
\text { чи взрослого; } \\
\text { единицы волитивной } \\
\text { модальности }\end{array}$ \\
\hline $\begin{array}{l}\text { Авторитар- } \\
\text { ный }\end{array}$ & $\begin{array}{l}\text { самоуверенно- } \\
\text { снисходитель- } \\
\text { ная, менторская, } \\
\text { пренебрежи- } \\
\text { тельная, презри- } \\
\text { тельная, } \\
\text { насмешливая, } \\
\text { иронично- } \\
\text { саркастическая }\end{array}$ & $\begin{array}{l}\text { демонстрация } \\
\text { власти взрос- } \\
\text { лого; } \\
\text { перенос ответ- } \\
\text { ственности } \\
\text { на ребенка; } \\
\text { подчеркивание } \\
\text { подчинитель- } \\
\text { ного положе- } \\
\text { ния ребенка }\end{array}$ & $\begin{array}{l}\text { импозитивность } \\
\text { (негатив, критика); } \\
\text { значительная по } \\
\text { объему речевая } \\
\text { партия взрослого; } \\
\text { немотивирован- } \\
\text { ные запреты; } \\
\text { вербальная агрес- } \\
\text { сия }\end{array}$ & $\begin{array}{l}\text { императивы, } \\
\text { условные предло- } \\
\text { жения, угрозы, } \\
\text { отсутствие этикет- } \\
\text { ных форм общения }\end{array}$ & $\begin{array}{l}\text { модальные формы } \\
\text { предсказания будуще- } \\
\text { го с наречем never, } \\
\text { сниженная / } \\
\text { грубая / вульгарная } \\
\text { лексика, } \\
\text { оскорбления, метафо- } \\
\text { рически-обидные } \\
\text { именования }\end{array}$ \\
\hline
\end{tabular}

Как отмечалось выше, воспитывающий стиль коммуникации в рамках англосаксонской культуры непременно опирается на такие ценности, как privacy, autonomy, individualism, freedom from imposition, что объясняет стремление взрослых придерживаться сдержанных манер и форм тональности, внушающих правила и нормы жизни с помощью обращения к разуму ребенка, демонстрации интереса и позитивного настроя взрослого, к формам, смягчающим критику поведения ребенка, и для этого прежде всего избираются стратегии и тактики демократического и интерпретативного стилей общения.

Для демократического стиля характерно использование стилистически нейтральных, неимперативных утверждений, уважительные обращения к ребенку, доминирование приемов преувеличения в хвалебных отзывах. Прагматика укора и критики выражается с помощью условных и гипотетических модальных предикативных конструкций, позволяющих смягчить негативное и оказать неимпозитивное воздействие на ребенка, напр.:

(1) If you don't show good manners at other people's houses, they are less likely to invite you back (VI, p. 67).

(2) When you yell during your brother's study time, you tell me you've decided to play in your room (III, p. 30).

Наблюдается активное использование языковых средств для реализации интенции желательности совершения ребенком действия, основанного на осознании значимости просьбы взрослого: 
(3) Mother: Dear, would you please turn the TV off? Son: Ok, Mom (IV, min. 12).

Побуждая ребенка к действию, условные предложения позволяют избегать прямого давления, служат сигналом, что взрослый ведет диалог в серьезной тональности, но готов к компромиссам, давая ребенку право на принятие решения, напр.:

(4) If you clean the table, I'll let you watch the film late tonight (IV, min. 56).

Для реализации интенции кооперативного взаимодействия и сотрудничества, характерной для демократического стиля общения, взрослый обычно избирает доброжелательную, дружелюбную, доверительную, серьезную коммуникативную тональности, позволяющие добиваться социализирующей цели путем апелляции к разуму ребенка:

(5) Can I watch television? - If you can do it so it doesn't disturb others. You decide (IV, p. 9).

(6) Would you rather stay at home or go with us? (IV, min. 116).

В реальной речевой практике наблюдается гибридное использование форм коммуникативной тональности, характерных для демократического стиля общения. Здесь проявляется стремление взрослого склонить ребенка к послушанию с помощью чередования высказываний, маркированных иллокутивными силами информирования, убеждения, косвенной критики. В следующем примере взрослый эксплицитно демонстрирует свою непреклонность:

(7) Child: What's for breakfast? - Adult: French toast. - Child: But I hate French toast. - Adult: I thought you liked it. - Child: Well, I don't. I hate it. Adult: When did you start hating French toast? Child: I don't know. I've always hated it. You just don't pay attention (VI, p. 89).

С помощью подчеркнуто-вежливой тональности взрослый может поставить условие, предлагая ребенку самостоятельно принять решение:

(8) Well, that's what's for breakfast. If you want something else, you have two perfectly good hands and know where the food is (VI, p. 89).
(9) Well, that's what's for breakfast. If you don't like it you don't have to eat it (VI, p. 89).

Воспитывающая роль взрослого предполагает, в первую очередь, оценивание действий ребенка с целью моделирования общественно и социально одобряемого поведения. При этом неизбежно возникает потребность вмешательства в его личное пространство. В случае демократического стиля общения последнее осуществляется с помощью высказываний с кооперативно-дружелюбными тональностями, реализуемыми посредством лексических и стилистических средств смягчения критики и выражения нежесткого по форме волеизъявления взрослого. Например, выбор синтаксически сложных конструкций предложений с описанием чувств, эмоций, a также вопросов и переспросов, побудительных предложений отражает интенцию приглашения ребенка к совместным действиям и самостоятельным выводам:

(10) I feel frustrated when I find empty milk cartons in the fridge and I wish you'd put them in the trash next time (III, p. 258).

(11) That sounds depressing. You are choosing to go out of turn (IV, min. 78).

(12) Please, make a decision to follow the rule or to choose a different activity (III, p. 30).

В приводимом далее диалоге отмечается доверительная тональность при общении матери с сыном, о чем свидетельствуют междометия $(O h)$, лексические и синтаксические повторы (I don't know), а многократное использование глагола to miss указывает на эмоциональную вовлеченность и эмпатию взрослого, стремление показать, что мать понимает сына и сопереживает:

(13) Son: What do you miss about him? Mother: Oh, I miss so many things about him. - Son: I miss how he could tell the weather just by touching the window. - Mother: When he would come in the house and yell: "What's everybody doing?" - Son: I miss how he would stick his entire arm into the coffee beans at Fairway...because he liked how it felt. Mother: That would make me so angry because everyone in the store was watching him. - Son: Were they? - Mother: Oh, I don't know. I don't know. I miss his voice. I miss his voice telling me he loves me. Son: Me too. Mom? It's okay if you fall in love again. 
If you want to. - Mother: I'll never fall in love for the first time again. Nobody can be him. - Son: He told me. He said: "I really love your mother. She's such a good girl." Mom, I don't tell you I love you enough times, do I? - Mother: Yes, you do. Oh, baby. You do (I, min. 1.51-1.53).

Как следует из примера, доверительная тональность может быть вербализована сопоставимым объемом высказываний партнеров по коммуникации, краткими ответами (You $d o)$, указывающими на правильность поведения ребенка. Выбор доверительной тональности позволяет смягчить контролирующую роль взрослого. В этом случае она реализуется перфомативами речемыслительной деятельности to want, to prefer, to choose, to pick, to decide в сочетании с mbl-обращением к ребенку (You decide / it is up to you / it is your decision / you can choose).

Коммуникативная неудача воспитывающего воздействия может подтолкнуть взрослого к смене демократического стиля на патерналистский, при этом появляются явные знаки указания на статусное неравенство коммуникантов по возрасту и социальному положению. В этом случае взрослый, не нарушая конвенции вежливости, избирает манеру общения с тональностями покровительства, открытого морализаторства, снисходительного дружелюбия, указывающие на интенцию волитивности и доминирования. Типичными становятся сочетания наречий too / enough с прилагательными young / old, указывающие на несостоятельность ребенка при принятии решения (You are not old enough to understand I I feel you are too young to be out at such a late hour), доминирование личного местоимения $I$ или притяжательного местоимения $m y$ напоминает о статусном превосходстве взрослого (That is what I have decided / It's my decision / I will decide what is good for my son). Мотивированные запреты (it is not okay for you to talk to me in that manner), выбор взрослым сослагательного наклонения демонстрируют доминирующий статус и превосходство (You'd better / If I were you / You can make better friends).

Анализ материала показал, что, несмотря на стремление взрослого следовать принятым в англосаксонском обществе манерам, для достижения главной задачи воспитыва- ющей коммуникации - социализации ребенка - взрослый может нарушать конвенции вежливости, сдержанности, уважения личности и обращаться к авторитарному стилю общения с его специфическими формами коммуникативной тональности. В таких ситуациях воспитывающий прибегает к императивным формам и синтаксическим конструкциям условия для передачи менторской тональности принуждения:

(14) Mother: Blake, you stay right there.-Boy: I want Nickolas. - Mother: Listen to me. Listen to me. I told you to stop. You do not stay on the road. You do not run in the road. And you do not tell me No. Come on. - Boy: But I want ... - Mother: You can not run in the road. Why? Because it's dangerous and a car could come and hurt you. Roads are for cars. They are not for people (IV, min. 12).

Обращение к модальному предикативу в сопровождении наречия never передает отсутствие веры взрослого в успешность развития ребенка (You will never amount to anything good, anybody can do it). Императивы и метафорические перифразы при именовании ребенка выражают саркастическую тональность (Well, look who's here. It's Mr. Cheerful). На презрение в речевых партиях взрослого указывает использование сниженной лексики (You cocky, self-centered little shit! Don't be more of a fool that God made you, girl! How dare you talk to me like that?), прилагательных со значением неприятных, отрицательных ощущений ( ' $^{\prime} m$ disgusted by you, do you hear me?), модальных предикатов, выражающих негативное отношение к ребенку как личности (I can't stand you). Авторитарность передается и с помощью знаков агрессивной коммуникативной тональности - общих вопросов, задаваемых для переспроса с интенцией принуждения к послушанию (Do you understand? / Is that clear?), существительных, призванных вызвать печальные, фатальные эмоции у ребенка (You are going to be the death of me; I am glad your dead grandmother isn't here to see this). Признаком пренебрежительной, презрительной, ироничной, саркастической коммуникативных тональностей является выбор взрослым инвективной, вульгарной лексики, напр.: 
(15) Don't be a sissy. There's nothing wrong with the Park, kid. It's just a school. They're all the bloody same. (II, p. 16).

В реальной коммуникации наблюдаются нарушения конвенций по признаку коммуникативной тональности, что может быть вызвано разными естественными причинами, например, социально-ролевым статусом взрослого, его эмоциональным настроем, эмоциональной атмосферой общения, непослушанием ребенка. В следующем примере отец изначально выбрал для общения с сыном патерналистский стиль с интенцией убедить его, что быть эгоистичным нехорошо (то есть он пытается навязать ребенку готовое решение):

(16) Father: Actually... I think it's a much better idea that you stay here with your mom and Neal. Son: But Dad! - Father: No buts, Charlie. I can't be selfish. I can't be with you all the time. We're a family. You, me, your mom, and Neal. And they need to be with you too. (The boy starts crying). - Father: Listen to me. Come here, listen, listen. There is a lot of kids out there, OK? Millions of kids. And they all believe in me. They are counting on me, Charlie. I'm not gonna let them down. I got a lot of work to do. So I can't be selfish, either? (V, min. 1.24-1.25).

В начале диалога его речевое поведение отличает снисходительно-дружелюбная тональность. Осознав, что не достиг желаемой цели (подчинения), он меняет тональность на серьезную и переходит к интерпретативному стилю (уговаривает, информирует), побуждая ребенка самостоятельно выбрать правильное решение. О серьезной тональности разговора свидетельствуют краткие отрицательные предложения, в которых повторяется модальный глагол can 't. Продолжая уговаривать плачущего ребенка, отец чередует доброжелательную тональность с доверительной.

Общение взрослых с подростками часто бывает конфликтным из-за их нежелания подчиняться власти взрослого. Нацеленность на решение задач социализации приводит к необходимости манипуляций, связанных с модуляциями коммуникативных тональностей речи взрослых. В следующем примере непослушание ребенка вынуждает родителя использовать разные тактики авторитарного и патерналистского стилей, переходить от иронично- насмешливой к агрессивной и далее менторской тональности:

(17) Don't you dare talk to me that way, young lady (VI, p. 20) (авторитарный стиль, тактика принуждения через запрет, агрессивная тональность с элементами насмешки).

(18) I'll talk to you any way I want. You just better watch it (VI, p. 20) (авторитарный стиль, тактика принуждения через угрозу, агрессивная тональность).

(19) What are you going to do, hit me? You would like that.You're just going to have to control your mouth before somebody does smack you (VI, p. 20) (авторитарный стиль, тактика принуждения через угрозу, агрессивная тональность).

(20) You're just mad because you can't control me anymore. You're going to have to learn to respect adults (VI, p. 20) (переход от авторитарного к патерналистскому стилю, менторская тональность).

Итак, проведенный лингвопрагматический анализ стилей воспитывающего общения показал, что в англосаксонской традиции воспитательного дискурса наиболее востребованными являются неимпозитивные стили демократического и патерналистского диалога, в них объединяются коммуникативные тональности с иллокутивной силой оказания поддержки, стремления к кооперации, разделению ответственности, предоставлению ребенку права выбора. Однако в случае коммуникативной неудачи взрослый меняет тактику и прямо апеллирует к своему доминирующему статусу, меняет тональность общения, избирая патерналистские или авторитарные приемы речи, что отражается в сочетании импозитивных и неимпозитивных приемов воспитывающей коммуникации.

\section{Заключение}

Изучение коммуникативных практик в ситуациях воспитывающего воздействия, нацеленных на передачу взрослыми информации о морально-нравственных устоях общества, этикете поведения, нормах бытового поведения, представляется актуальным как в плане развития теории воспитательного дискурса, так и в прикладном аспекте, поскольку успех воспитательного процесса требует от взрослых (профессионалов и родителей) владения разными стилями воспитывающего воздей- 
ствия. Как свидетельствуют результаты проведенного исследования, воспитатель-профессионал или родитель с целью социализации ребенка, ориентируясь на его возраст и интеллектуальный уровень, избирает ту тональность и стилистику общения, которая в большей степени соответствует интенциям и социокультурным условиям интеракции с ребенком (в частности, его психотипу, уровню доверия взрослым, степени принятого дистанцирования по социально-ролевым различиям между взрослым и ребенком, уровнем усвоения норм морали и этики своего социума, норм культуры поведения дома и в публичном месте). Воспитывающие коммуникативные действия отличаются гибридностью, связанной с выбором одного из допустимых стилей общения (демократического, патерналистского, авторитарного, интерпретативного). В реальном общении они ранжируются по степени импозитивности / неимпозитивности, имплицитности / эксплицитности демонстрации статусной асимметрии взрослого и ребенка, что получает отражение в модуляциях коммуникативной тональности общения от дружелюбной, склоняющей к кооперативности, к серьезной, призывающей к логичным действиям и решениям, и далее к снисходительно-патерналистской или агрессивно-оскорбительной. В случае коммуникативной неудачи взрослый, сохраняя мотив воспитывающей коммуникации, применяет механизм тематической и прагмастилистической модуляции, подбирая более подходящий ситуации стиль воспитывающего общения и чередуя тактики и тональности разговора, что находит выражение в специфическом наборе речевых приемов и синтаксических моделей английского языка.

\section{СПИСОК ЛИТЕРАТУРЫ}

Алексеева Т. А., 2013. Криминалистическая характеристика тональности как структурного элемента устной речи // Вестник Томского государственного университета. № 376. С. 124-125. DOI: 10.17223/15617793/376/23.

Бахтин М. М., 1997. Проблема речевых жанров. Из архивных записей к работе «Проблема речевых жанров» // Собрание сочинений. В 7 т. Т. 5. Работы 1940-х - начала 1960-х годов. М. : Русские словари : Языки славянских культур. C. $159-286$.
Гальперин И. Р., 2005. Избранные труды. М. : Высшая школа. $255 \mathrm{c}$.

Грановская Р. М., 2007. Элементы практической психологии. СПб. : Речь. 655 с.

Ильинова Е. Ю., Цинкерман Т. Н., 2015. Стратегические трансформации и прагматические модуляции стилей воспитывающего общения в англоязычном воспитательном дискурсе // Грани познания. № 1 (35). C. 1-5. URL: http://grani. vspu.ru/jurnal/40.

Карасик В. И., 2007. Языковые ключи. Волгоград : Парадигма. $520 \mathrm{c}$.

Карасик В. И., 2008. Коммуникативная тональность // Вестник Северо-Осетинского государственного университета им. К.Л. Хетагурова. № 4. C. 20-29.

Карасик В. И., 2013. Языковая матрица культуры. М. : Гнозис. 320 c.

Куликова Л. В., 2011. Стилевой формат межкультурного дискурса // Вестник Иркутского государственного лингвистического университета. № 1. C. 76-82.

Ларина Т. В., 2013. Англичане и русские: Язык, культура, коммуникация. М. : Языки славянских культур. 360 с.

Леонтович О. А., 2002. Русские и американцы: парадоксы межкультурного общения. Волгоград : Перемена. $434 \mathrm{c}$.

Матвеева Т. В., 2003. Тональность // Стилистический энциклопедический словарь русского языка / под ред. М. Н. Кожиной. М. : Флинта : Наука. C. 549-552. URL: https://stylistics.academic.ru/ 222/ (дата обращения: 20.11.2018).

Тупикова С. Е., 2011. Категория тональности и уровни ее репрезентации в жанре светской хроники // Вопросы когнитивной лингвистики. Вып. 4. С. 68-73.

Цинкерман Т. Н., 2015. Об опыте диахронического подхода к установлению динамики ценностей англоязычного воспитательного дискурса // Вестник Волгоградского государственного университета. Серия 2, Языкознание. № 5 (29). C. 101-107. DOI: http://dx.doi.org/10/15688/ jvolsu2.2015.5.11.

Эффективное речевое общение (базовые компетенции), 2012. Словарь-справочник / под ред. А. П. Сковородникова. Красноярск : Изд-во Сиб. гос. ун-та. 882 c.

Hunter A., 1994. Etiquette: A guide to modern manners. Glasgow : Harper Collins Publishers. 256 p.

Norton R. W., Pettegrew L. S., 1977. Communicator style as an effect determinant of attraction// Communication Research. Vol. 4,№3. P. 257-282.

Pearson J., Nelson P., Titsworth S., Harter L., 2012. Human communication. $5^{\text {th }}$ edition. New York : McGraw-Hill. 448 p. 
The Accidental Communicator. URL: http:// theaccidentalcommunicator.com/present/itturns-out-that-tonality-is-what-really-matters (date of access: 28.10.2018).

\section{ИСТОЧНИКИ}

I - Extremely Loud and Incredibly Close. Scott Rudin Productions, 2012.

II - Harris J. Gentlemen\&Players. London : Black Swan, 2006. 512 p.

III - Moorman Ch. Parent Talk: How to talk to your Children in language that builds self-esteem and encourages responsibility. New York : Fireside, 2003. 320 p.

$I V$ - Supernanny: When Little Kids Cause Big Headaches. Acorn Media UK Ltd, 2010.

$V$ - The Santa Claus. Walt Disney Pictures, 1994.

$V I$ - WolfAnthony E. I'd listen to my parents if they'd just shut up. What to Say and Not Say When Parenting Teens. Harper ; New York ; London ; Toronto ; Sydney : HarperCollins Publishers, 2011. 289 p.

\section{REFERENCES}

Alekseeva T.A., 2013. The Criminalistic Description of Vocalicity as a Structural Element of Oral Speech. Vestnik Tomskogo gosudarstvennogo universiteta [Tomsk State University Journal], no. 376, pp. 124-125. DOI: 10.17223/15617793/ 376/23

Bakhtin M.M., 1997. Problema rechevyhh zhanrov. Iz arkhivnykh zapisey k rabote "Problema rechevykh zhanrov" [The Problem with Speech Genres. From Archive Records to Work "The Problem with Speech Genres"]. Sobranie sochineniy. V7 t. T. 5. Raboty 1940-h-nachala 1960-h godov [Coll. works of 7 vols. Works of the 1940s - early 1960s.]. Moscow, Russkie slovari Publ., Yazyki slavyanskikh kultur Publ., pp. 159-286.

Galperin I.R., 2005. Izbranniye trudy [Selected Works]. Moscow, Visshaya shkola Publ. 255 p.

Granovskaya R.M., 2007. Elementy prakticheskoy psykhologii [Constituent Elements of Practical Psychology]. Saint Petersburg, Rech Publ. 655 p.

Ilyinova E.Yu., Tsinkerman T.N., 2015. Strategic Transformations and Pragmatic Modulations of Educative Communicative Styles in English Educational Discourse. Grani poznaniya, no. 1 (35), pp. 1-5. URL: http://grani.vspu.ru/jurnal/40.

Karasik V.I., 2007. Yazykovye klyuchi [Langugae Keys]. Volgograd, Paradigma Publ. 520 p.
Karasik V.I., 2008. Communicative Tonality. Vestnik Severo-Osetinskogo gosudarstvennogo universiteta im. K.L. Hetagurova [Vestnik of North Ossetian State University after K.L. Khetagurov], no. 4, pp. 20-29.

Karasik V.I., 2013. Yazykovaya matritsa kultury [Language Matrix of Culture]. Moscow, Gnozis Publ. 320 p.

Kulikova L.V., 2011. The "Style" Dimension of Intercultural Discourse. Vestnik Irkutskogo gosudarstvennogo lingvisticheskogo universiteta, no. 1, pp. $76-82$.

Larina T.V., 2013. Anglichane i russkie: Yazyk, kultura, kommunikatsiya [The English and The Russians: Language, Culture, Communication]. Moscow, Yazyki slavyanskikh kultur Publ. $360 \mathrm{p}$.

Leontovich O.A., 2002. Russkie $i$ amerikantsy: paradoksy mezhkulturnogo obshcheniya [Russians and Americans: Problems of Crosscultural Communication]. Volgograd, Peremena Publ., 2002. 434 p.

Matveeva T.V., 2003. Tonality. Stylistic Encyclopedic Dictionary of the Russian Language. Moscow, Flinta Publ., Nauka Publ., pp. 549-552. URL: https://stylistics.academic.ru/222/ (Accessed 20 November 2018).

Tupikova S.E., 2011. The Category of Tonality and Its Levels of Representation in Society Column Genre. Voprosy kognitivnoy lingvistiki [Issues of Cognitive Linguistics], iss. 4 , pp. 68-73.

Tsinkerman T.N., 2015. Dynamics of Values in English Educative Discourse via Diachronic Approach. Vestnik Volgogradskogo gosudarstvennogo universiteta. Seriya 2, Yazykoznanie [Science Journal of Volgograd State University. Linguistics], no. 5 (29), pp. 101-107. DOI: http://dx.doi.org/10/15688/ jvolsu2.2015.5.11.

Skovorodnikov A.P., ed., 2012. Efficient Conversation (Basic Competences). Slovar-spravochnik [Reference Dictionary]. Krasnoyarsk, Izd-vo Sibirskogo gosudarstvennogo universiteta. $882 \mathrm{p}$.

Hunter A., 1994. Etiquette: A Guide to Modern Manners. Glasgow, Harper Collins Publishers. $256 \mathrm{p}$.

Norton R.W., Pettegrew L.S., 1977. Communicator Style as an Effect Determinant of Attraction. Communication Research, no. 4(3). pp. 257-282.

Pearson J., Nelson P., Titsworth S., Harter L., 2012. Human communication. $5^{\text {th }}$ ed. New York, McGraw-Hill. 448 p.

The Accidental Communicator. URL: http:// theaccidentalcommunicator.com/present/it- 
turns-out-that-tonality-is-what-really-matters (Accessed 28 October 2018).

\section{SOURCES}

Extremely Loud and Incredibly Close. Scott Rudin Productions, 2012.

Harris J. Gentlemen\&Players. London, Black Swan, 2006. 512 p.

Moorman Ch. Parent Talk: How to Talk to Your Children in Language That Builds Self-Esteem and Encourages Responsibility. New York, Fireside, 2003. 320 p.

Supernanny: When Little Kids Cause Big Headaches. Acorn Media UK Ltd, 2010.

The Santa Claus. Walt Disney Pictures, 1994.

Wolf Anthony E. I'd Listen to My Parents If They'd Just Shut Up. What to Say and Not Say When Parenting Teens. Harper, New York, London, Toronto, Sydney, Harper Collins Publishers, 2011.289 p.

\section{Information about the Authors}

Elena Yu. Ilyinova, Doctor of Sciences (Philology), Professor, Department of English Philology, Volgograd State University, Prosp. Universitetsky, 100, 400062 Volgograd, Russia, ilynov@volsu.ru, english_philolog@mail.ru, http://orcid.org/0000-0002-3310-4020

Tamara N. Tsinkerman, Candidate of Sciences (Philology), Associate Professor, Department of English Philology, Volgograd State University, Prosp. Universitetsky, 100, 400062 Volgograd, Russia, tsinkerman@volsu.ru, english_philolog@mail.ru, https://orcid.org/0000-0002-0258-974X

\section{Информация об авторах}

Елена Юрьевна Ильинова, доктор филологических наук, профессор кафедры английской филологии, Волгоградский государственный университет, просп. Университетский, 100, 400062 г. Волгоград, Россия, ilynov@volsu.ru, english_philolog@mail.ru, http://orcid.org/0000-0002-3310-4020

Тамара Николаевна Цинкерман, кандидат филологических наук, доцент кафедры английской филологии, Волгоградский государственный университет, просп. Университетский, 100, 400062 г. Волгоград, Россия, tsinkerman@volsu.ru, english_philolog@mail.ru, https://orcid.org/00000002-0258-974X 